\title{
COMPETENCIES IN THE NURSE EDUCATION PROCESS TO CARE FOR THE AGING: AN INTEGRATIVE REVIEW
}

\author{
Carla Francine de Andrade Perez ${ }^{1}$, Francis Solange Vieira Tourinho ${ }^{2}$, Paulo Marcondes Carvalho Júnior ${ }^{3}$
}

\footnotetext{
${ }^{1}$ Master student, Programa de Pós-Graduação em Saúde e Envelhecimento, Faculdade de Medicina de Marília (FAMEMA). CAPES scholarship. Marília, Paraná, Brazil. E-mail: carla-andrade-@hotmail.com

2 Ph.D. in Children and Adolescents Health. Professor, Nursing Department, Universidade Federal de Santa Catarina. Florianópolis, Santa Catarina. Brazil. E-mail: francis.tourinho@ufsc.br

${ }^{3}$ Ph.D. in Biomedical Engineering. Professor, FAMEMA. Marília, Paraná, Brazil. E-mail: marcondes.paulo@gmail.com
}

\begin{abstract}
The aim of this study was to synthesize the knowledge produced about nursing students' education process in national databases, considering the curricular proposal of competency-based guidance related to care for the aging. An integrative review was performed in LILACS and BDENF bases with the following descriptors: "geriatric nursing", "gerontological nursing" and "education." Content analysis was applied in the articles. Subsequently, word clouds were built. In the seventeen articles that met the inclusion and exclusion criteria, the main topics discussed were elderly, aging, old age, gerontology and geriatrics, geriatric nursing, care for the elderly and academic education. The lack of studies that address the competencies to care for the aging in a more structured way in undergraduate nursing courses was, therefore, observes through this research. Articles generally address the curricula structures guided by the National Curriculum Guidelines for Nursing Courses, with the focus on knowledge transmission, usually following the traditional methodology. DESCRIPTORS: Professional competence. Education, nursing, diploma programs. Aging.
\end{abstract}

\section{COMPETÊNCIAS NO PROCESSO DE FORMAÇÃO DO ENFERMEIRO PARA O CUIDADO AO ENVELHECIMENTO: REVISÃO INTEGRATIVA}

RESUMO: O objetivo deste estudo foi sintetizar os estudos produzidos nas bases de dados nacionais sobre processo de formação de estudantes de enfermagem, considerando a proposta curricular orientada por competências profissionais relacionadas ao cuidado ao envelhecimento. Foi realizada uma revisão integrativa nas bases LILACS e BDENF com os seguintes descritores: "enfermagem geriátrica", "enfermagem gerontológica" e "educação". Para análise dos artigos foi utilizada a análise de conteúdo. Em seguida foram construídas nuvens de palavras. Nos 17 artigos que preencheram os critérios de inclusão e exclusão, os principais temas abordados foram idoso, envelhecimento, velhice, gerontologia e geriatria, enfermagem gerontogeriátrica, cuidados aos idosos e formação acadêmica. Na pesquisa feita, é possível observar a ausência de estudos que abordem, de forma mais estruturada, as competências para o cuidado ao envelhecimento nos cursos de graduação em enfermagem. Os artigos abordam, geralmente, as estruturas de currículos orientados pelas Diretrizes Curriculares Nacionais para o Curso de Enfermagem, porém, predominantemente, na metodologia tradicional, com foco na transmissão do conhecimento.

DESCRITORES: Competência profissional. Programas de graduação em enfermagem. Envelhecimento.

\section{COMPETENCIAS EN EL PROCESO DE FORMACIÓN EN ENFERMERÍA PARA EL CUIDADO DEL ENVEJECIMIENTO: UNA REVISIÓN INTEGRATIVA}

\begin{abstract}
RESUMEN: Este estudio sintetiza los estudios realizados en las bases de datos sobre el proceso de formación de estudiantes de enfermería sobre los planes de estudio orientados en competencias profesionales relacionadas con el cuidado del envejecimiento. Revisión integrativa en las bases LILACS y BDENF con los descriptores: "enfermería geriátrica", "enfermería gerontológica" y "educación”. Para el análisis de los artículos se realizó un análisis de contenido, posteriormente fueron construidas nubes de palabras. En los 17 artículos que cumplían los criterios de inclusión y exclusión, los principales temas que se trataron fueron: edad, envejecimiento, vejez, gerontología y geriatría, enfermería geriátrica, atención a la formación de edad avanzada y formación académica. En los artículos encontrados es posible observar la ausencia de estudios que abordan de forma estructurada, las competencias para el cuidado del envejecimiento en los cursos de enfermería. Los artículos presentan estructuras curriculares basadas en las Directrices Curriculares Nacionales para la Carrera de Enfermería centrados en la transmisión del conocimiento con enfoque en la metodología tradicional.
\end{abstract}

DESCRIPTORES: Competencia profesional. Programas de graduación en enfermería. Envejecimiento. 


\section{INTRODUCTION}

The discussion on nursing academic education, with the inclusion of Geriatrics and Gerontology as disciplines in the academic curriculum has been taking place for a long time and was intensified with the implementation of the National Curriculum Guidelines, in 1994. Although the guidelines point to the use of competencies in health education, little is discussed about the curricular model, especially the competency-based curriculum focused on the care for the aging. The concept of professional competence has multiple meanings. One of them, in use, refers to the professional competencies as "the ability to articulately mobilize different resources (cognitive, affective, psychomotor) that allow to address/solve complex situations regarding professional practice". 1:35

Three axes or features constitute professional competencies: knowledge, understood here as the professional's knowledge; skills, understood as the expertise; and attitudes, here defined as knowing how to act, judge, choose and decide on a specific situation. $^{2}$

The publication of the National Elderly Policy (PNI, Politica Nacional do Idoso), ${ }^{3}$ based in this age group's demographic growth, establishes qualified service and human resources training as guidelines, among others. Therefore, there must be a reflection of this requirement in the structure and curriculum composition of nursing courses.

The competency-based approach in health education seeks to go beyond the simple transfer of theoretical knowledge. The learner needs to be inserted in practices where it is possible to exercise the mobilization of knowledge in complex situations, so that it can respond to the demand referred in the Curriculum Guidelines and in PNI, according to the needs of the SUS. ${ }^{4}$

The aging of population, the urge for competency-based professional education and legislation are factors that point to the urge of curricular reform and revision of literature on the topic to assist the development of real and effective academic programs for future generations of nurses and health professionals in general.

Thus, the question of this research was stipulated as: "how do published health articles reflect on nursing students' education process, considering professional competencies to care for the aging in undergraduate courses?"
The objective of this study was to synthesize the literature in national databases on the education process of nursing students into a competency-based curricular proposal focused on care for the aging.

\section{METHOD}

An integrative review ${ }^{5}$ was carried out according to the six steps pointed by Ganong. ${ }^{6-7}$

The literature revision was based in LILACS (Literatura Latino-Americana e do Caribe em Ciências da Saúde - Latin American and Caribbean Literature in Health Sciences) databases, and BDENF (Base de Dados Bibliográficos Especializada na área de Enfermagem - Specialized Bibliographic Database in Nursing), in the period of April, 2014.

The following descriptors were used: "geriatric nursing", "gerontological nursing" and "education", establishing the strategy: (nursing and (geriatr\$ or geronto $\left.\$^{*}\right)$ ) and (education), in the search platforms in order to find relevant results for the subject discussion.

For data collection, gathering and analysis of the works, the form validated by $\mathrm{Ursi}^{8}$ was used, whose goal is to ensure the extraction of all the relevant data, reduction of possible errors in transcription, ensure accuracy in information checking and also serve as a safe record.

The following criteria for selection were established: studies published in full in national journals and those who approached the theme of professional competence for nursing undergraduate course, with focus on aging or elderly.

Exclusion criteria were studies without a summary, duplicates, editorials, monographs, dissertations, theses, letters and international studies. Articles prior to the publication of the Curricular Guidelines for the undergraduate nursing program (in 2001) were not deleted, as they were considered important to the understanding of the process of the curriculum historic construction.

The selection and deletion of articles was supported by the reflections about the structuring elements of the published works. ${ }^{9}$ Finally, 63 articles were raised in total, 20 of them were about the proposed thematic and three have been deleted for being dissertations. Thus, there were seventeen articles left for the analysis.

Content analysis was developed for qualitative analysis. In order to illustrate the results, the word

\footnotetext{
The use of $\$$ has the function of searching for derived words beginning with the prefix used, in this case: gerontology,
} gerontologist, and others, facilitating the search. 
cloud tool, from Wordle ${ }^{\mathrm{TM}}$ app, was used. This is a tool for generating custom views by users. The results are presented as images that show the most prominent words. There is a correlation between word clouds and speech analysis, a thematic mode..$^{10}$ In this study, the words used were drawn from selected journals.

\section{RESULTS}

The articles' publication date ranged from 1988 to 2013. The main topics discussed were elderly, aging, age, gerontology and geriatrics, gerontological nursing, care for the elderly and academic education. As to the methodology used, there was predominance of qualitative methods. Three studies did not show description of the methodology. The articles' main data are synthesized in table 1.

The analysis of the data occurred, predominantly, by content analysis in qualitative research and simple frequency distribution, parametric and nonparametric statistical test (ANOVA), " $\mathrm{t}$ " of Student and Spearman-Cronbach Model for quantitative studies.

Table 1- Distribution of publications on the topic nursing competencies to elderly care, according to article title, periodical, study method, type of data analysis and search site. Marília-SP, Brazil, 2014

\begin{tabular}{|c|c|c|c|}
\hline Title & Journal & Method & Data analysis \\
\hline $\begin{array}{l}\text { A imagem da velhice: a ótica do estudante de Enfer- } \\
\text { magem }^{11}\end{array}$ & $\begin{array}{l}\text { Nursing (São Paulo). 2002; } \\
\text { 50(5):19-24. }\end{array}$ & Qualitative & Subject discourse \\
\hline $\begin{array}{l}\text { Algumas reflexões sobre o ensino da enfermagem } \\
\text { geronto-geriátrica na UFSC }{ }^{12}\end{array}$ & $\begin{array}{l}\text { Texto Contexto Enferm. } \\
\text { 1999; 8(1):174-85. }\end{array}$ & Reflection & - \\
\hline $\begin{array}{l}\text { Atitudes e conhecimentos em relação à velhice em } \\
\text { estudantes de graduação em educação e em saúde: } \\
\text { subsidios ao planejamento curricular }{ }^{13}\end{array}$ & $\begin{array}{l}\text { Estud Psicol. 2006; } \\
\text { 23(2):127-37. }\end{array}$ & $\begin{array}{l}\text { Quantitative and } \\
\text { descriptive }\end{array}$ & $\begin{array}{l}\text { Palmore-Neri- } \\
\text { Cachioni Scale. } \\
\text { Semantic differen- } \\
\text { tial scale } \\
\text { Statistical tests. } \\
\end{array}$ \\
\hline $\begin{array}{l}\text { Avaliação do ensino da disciplina enfermagem } \\
\text { gerontogeriátrica do curso de graduação em enferma- } \\
\text { gem da FURG }{ }^{14}\end{array}$ & $\begin{array}{l}\text { Cogitare Enferm. 2007; } \\
\text { 12(1):82-8. }\end{array}$ & $\begin{array}{l}\text { Qualitative, histor- } \\
\text { ical-organization } \\
\text { case type }\end{array}$ & Content analysis \\
\hline $\begin{array}{l}\text { Enfermagem geronto-geriatrica: proposta curricu- } \\
\text { lar }\end{array}$ & $\begin{array}{l}\text { Rev Paul Enferm. 1993; } \\
\text { 12(2):228-35. }\end{array}$ & - & - \\
\hline $\begin{array}{l}\text { Enfermagem gerontológica: a produção do conheci- } \\
\text { mento na profissão (1970-1996) }\end{array}$ & $\begin{array}{l}\text { Rev Gaúcha Enferm. 2013; } \\
\text { 34(1):86-93. }\end{array}$ & $\begin{array}{l}\text { Descriptive and } \\
\text { qualitative }\end{array}$ & $\begin{array}{l}\text { Content analysis } \\
\text { technique }\end{array}$ \\
\hline $\begin{array}{l}\text { Ensino de enfermagem gerontológica na graduação } \\
\text { das instituições públicas do Estado de Minas Gerais }{ }^{17}\end{array}$ & $\begin{array}{l}\text { Rev Min Enferm. 2007; } \\
\text { 11(1): 26-31. }\end{array}$ & $\begin{array}{l}\text { Qualitative/quan- } \\
\text { titative } \\
\text { Descriptive-explor- } \\
\text { atory } \\
\end{array}$ & $\begin{array}{l}\text { Simple frequency } \\
\text { distribution/Con- } \\
\text { tent Analysis }\end{array}$ \\
\hline $\begin{array}{l}\text { Ensino de gerontologia e geriatria: uma necessidade } \\
\text { para os acadêmicos da área de saúde da Universidade } \\
\text { Federal do Triângulo Mineiro? }{ }^{18}\end{array}$ & $\begin{array}{l}\text { Cienc Cuid Saude 2008; } \\
7(4): 537-45 \text {. }\end{array}$ & $\begin{array}{l}\text { Quantitative } \\
\text { Transversal De- } \\
\text { scriptive } \\
\end{array}$ & - \\
\hline $\begin{array}{l}\text { Ensino sobre idoso e gerontologia: visão dos discentes } \\
\text { de enfermagem no Estado de Minas Gerais }{ }^{19}\end{array}$ & $\begin{array}{l}\text { Texto Contexto Enferm. } \\
2006 ; 15(4): 663-71 \text {. }\end{array}$ & $\begin{array}{l}\text { Qualitative/quan- } \\
\text { titative Descriptive } \\
\text { exploratory }\end{array}$ & $\begin{array}{l}\text { Content analysis/ } \\
\text { Frequency distribu- } \\
\text { tion }\end{array}$ \\
\hline $\begin{array}{l}\text { Graduandos de enfermagem na formação de cuida- } \\
\text { dores de idosos: relato de experiência }\end{array}$ & $\begin{array}{l}\text { Acta Paul Enferm. 1995; } \\
\text { 8(4):76-81. }\end{array}$ & Experience report & - \\
\hline $\begin{array}{l}\text { O ensino da enfermagem gerontogeriatrica e a com- } \\
\text { plexidade }{ }^{21}\end{array}$ & $\begin{array}{l}\text { Rev Esc Enferm USP. 2006; } \\
\text { 40(2):228-35. }\end{array}$ & Qualitative & Qualitative analysis \\
\hline $\begin{array}{l}\text { O ensino de enfermagem geriátrica a partir do do- } \\
\text { micílio do idoso - relato de experiência }{ }^{22}\end{array}$ & $\begin{array}{l}\text { Rev Baiana Enferm. 1998; } \\
\text { 4(1):8-11. }\end{array}$ & Experience report & - \\
\hline $\begin{array}{l}\text { O ensino sobre o processo de envelhecimento e vel- } \\
\text { hice nos cursos de graduação em enfermagem }\end{array}$ & $\begin{array}{l}\text { Rev Bras Enferm. 2003; } \\
\text { 56(5):502-7. }\end{array}$ & $\begin{array}{l}\text { Qualitative } \\
\text { Descriptive and } \\
\text { exploratory }\end{array}$ & Thematic analysis \\
\hline $\begin{array}{l}\text { O envelhecimento e o idoso no ensino de graduação } \\
\text { em enfermagem no Brasil: do panorama atual à uma } \\
\text { proposta de conteúdo programático }{ }^{24}\end{array}$ & $\begin{array}{l}\text { Rev Esc Enferm USP. 1999; } \\
\text { 33(4):370-6. }\end{array}$ & $\begin{array}{l}\text { Quantitative } \\
\text { Descriptive }\end{array}$ & - \\
\hline
\end{tabular}




\begin{tabular}{|l|l|l|c|}
\hline \multicolumn{1}{|c|}{ Title } & \multicolumn{1}{|c|}{ Journal } & \multicolumn{1}{c|}{ Method } & \multicolumn{1}{c|}{ Data analysis } \\
\hline $\begin{array}{l}\text { Percepção de acadêmicos de enfermagem sobre o } \\
\text { cuidar de idosos }^{25}\end{array}$ & $\begin{array}{l}\text { Cogitare Enferm 2009 Jan/ } \\
\text { Mar; 14(1): 85-91. }\end{array}$ & $\begin{array}{l}\text { Qualitative } \\
\text { Analytical and } \\
\text { descriptive }\end{array}$ & Content analysis \\
\hline $\begin{array}{l}\text { Trabalhando o conceito de velhice com o estudante de } \\
\text { enfermagem }\end{array}$ & $\begin{array}{l}\text { Rev Med Minas Gerais. } \\
1998 ; 8(40): 152-6 .\end{array}$ & - & - \\
\hline $\begin{array}{l}\text { Visão de acadêmicos de enfermagem em relação ao } \\
\text { processo de envelhecimento }\end{array}$ & $\begin{array}{l}\text { Rev Rene. 2012; 13(4):825- } \\
33 .\end{array}$ & $\begin{array}{l}\text { Qualitative } \\
\text { Descriptive and } \\
\text { exploratory }\end{array}$ & Content analysis \\
\hline
\end{tabular}

The following thematic pillars were listed in the articles researched: competencies on elderly care in nursing academic education; disciplines implemented in nursing courses related to aging with proper workload for study and practice; strategies used in the competencies training process; and major students' perceptions about the structure of the academic curriculum of nursing and old age.

The competencies identified were transformed into word clouds and are illustrated in figure 1.

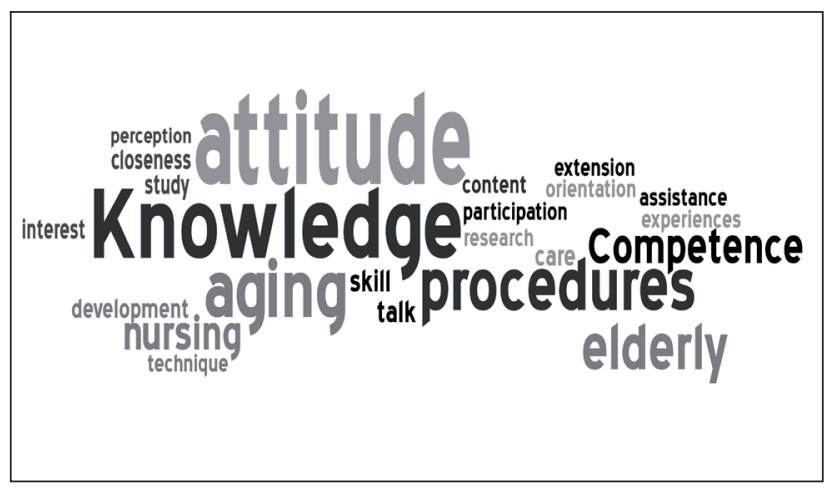

Figure 1 - Competencies to elderly care during undergraduate nursing courses, according to revised articles. Marília-SP, Brazil, 2014

Local variations and information gaps were found concerning the workload of disciplines in view the aging process teaching. The content is worked between theoretical and practical classes, in the disciplines of Gerontological Nursing Care, Gerontological Care Foundations and Legal Aspects, Understanding of Senescence, involving general and specific aspects, Sociopolitical Aspects, Economic and Cultural Aspects of Aging, Senility, Elderly Healthcare in Different Contexts, Demographic and Epidemiological Aspects and Multidisciplinary Approach in Nursing Undergraduate Teaching.

Among the strategies used in competencybased education process, several were highlighted, as seen in the image of figure 2 . The diversity in the composition of the teaching-learning process in nursing courses of different institutions is shown here.

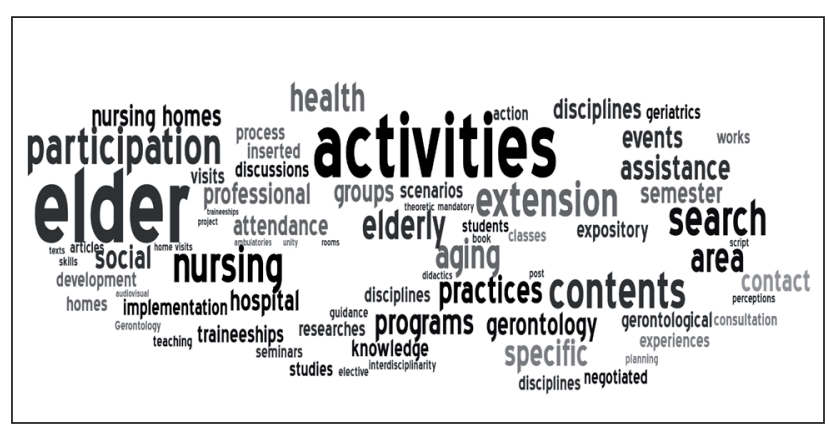

Figure 2 - Teaching-learning strategies used in competency-based education process. Marília-SP, Brazil, 2014

In the description of the didactic activities extracted from the articles it is possible to capture different perceptions from students and professors about the structure of nursing academic curriculum directed to elderly care, as shown in figure 3.

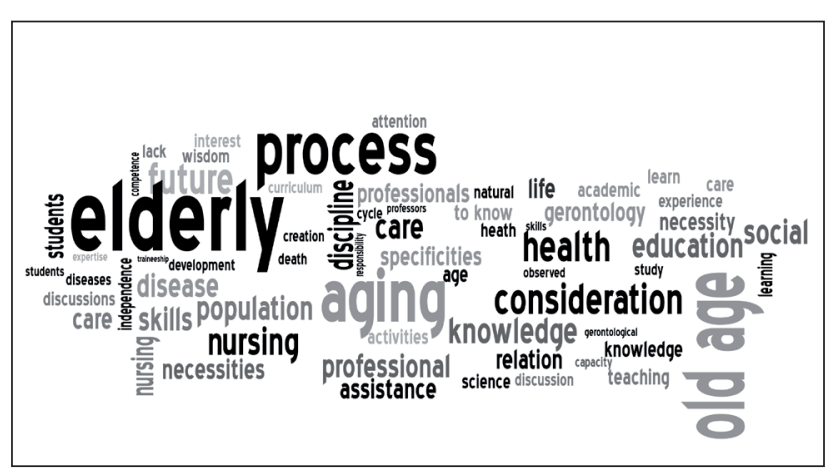

Figure 3 - Main perceptions from students and professors about the structure of the disciplines related to elderly care in nursing courses. MaríliaSP, Brazil, 2014

In figure 4, words that define the students' perceptions when asked about what old age is. 


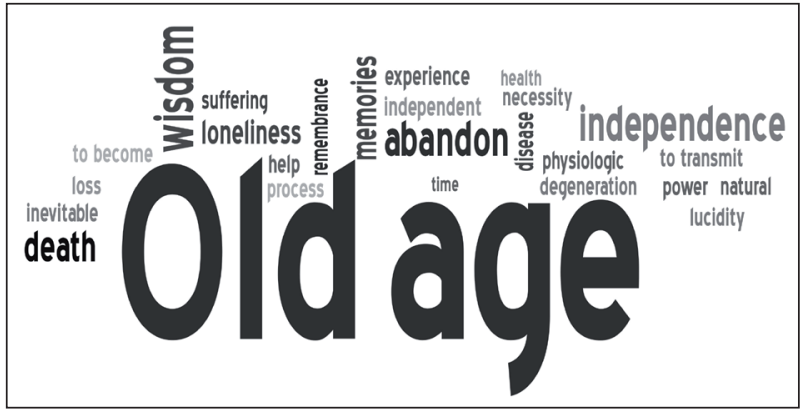

Figure 4 - Students' perceptions about what old age is. Marília-SP, Brazil, 2014

\section{DISCUSSION}

\section{Professional competence - word cloud in figure 1}

Professional competencies can be considered as essential aspects in the construction of pedagogical projects and academic curricula in nursing courses, according to the National Curriculum Guidelines (DCNs, Diretrizes Curriculares Nacionais). Consequently, they guide the professionals' education and thus, the competency-based curriculum model is privileged to leverage the changes happening in the work world, specifically in the health services. ${ }^{28}$

The concept of professional competence refers to a series of distinct philosophical chains. In essence, this concept relates to the elements or features that make up this competence. ${ }^{2}$ Thus, in the word cloud in figure 1, words highlighted are: "attitude" and "skill". The word "content" appears in smaller size, as well as "knowledge", "study" and "technique". Action words also appear, such as "to care", "to talk", "engagement", "closeness" and "guidance".

The aggregated knowledge, as "the knowledge acquired by the professional", ${ }^{2}$ was linked to the act of studying theoretical contents related to the process of aging and geriatrics. The abilities such as "specific professional expertise", under these authors perspective, may be correlated to extension and research projects and elderly assistance, focusing on the performance of the procedures.

\section{Curriculum organization, subjects and workload}

The reviewed articles indicated several ways to approach the content of curricular organization. In the international scope, gerontology is understood as the study of aging. Therefore, in its core, there is geriatrics, focused on prevention and treatment of diseases in old age, and the social gerontology, articulated with different areas, such as psychology, social work and law, and others. ${ }^{29}$

The discussion on nursing academic education, with the implementation of Geriatrics and Gerontology as disciplines in the academic curriculum, was intensified with the establishment of the National Curriculum Guidelines in 1994. In the late 90 s another curriculum proposal emerged for nursing undergraduate courses that covered the curricular principles proposed by $\mathrm{ABEn}$, i.e., to include the elderly in the area of nursing care. ${ }^{11}$ Thus, the undergraduate course becomes a privileged space to train competent professionals that are able to meet the social health needs. ${ }^{30}$

The disciplines in the reviewed articles of "Geriatric Nursing" and "Gerontology and Geriatrics" represent curricular proposals of this scientific area insertion in the teaching-learning process. An article proposes the discipline "Nursing in Adult and Elderly Health" to the fifth phase, in which the contents aging and elderly healthcare are discussed in adult health. Uniting adult and elderly has a historical component regarding the curriculum organization.

\section{Teaching strategies - word cloud in figure 2}

Practical scenarios can be considered as articulating tools for professional competence development. The word cloud shows learning processes based on practical activities. These practical activities occur with the elderly through the insertion of students in scenarios such as hospitals, nursing homes and home visits (HV). Experience in the practical field allows them to meet the diversity and heterogeneity of the aging process. It also provides involvement in research and knowledge of technological advances. Students begin to recognize the importance of interdisciplinary action in both theory and practice. They contribute to education programs for the aging; take on the challenges of the area in promoting health, well-being and quality of life for the elderly and promote this along with society, through educational actions, changes in perceptions and attitudes about old age and aging. ${ }^{13}$

Other activities also appear as teaching strategies. According to the reviewed articles, interdisciplinarity between research, extension, social participation, partial geriatric content offered integrated with other disciplines, and specific improvement 
appear as ideal training. Contents about the elderly in the curricular matrix, referring to concepts of geriatrics, gerontology, autonomy, independence, self-care, changes that occur in the aging process, promotion and prevention, palliative care, social support and weaknesses become necessary. The implementation of Geriatrics and Gerontology Leagues and Extension Projects and participation in scientific events are some of the strategies for an articulated and solid training.

An adequate curriculum organization provides in-depth study in gerontology in relation to elderly health care and makes it possible to know the primary health needs of this population, as well as to outline potential measures to improve assistance. The aim is health prevention, promotion and rehabilitation. This knowledge improves the training of specialized professionals to assist this clientele. ${ }^{17}$

The integrality of care must also contextualize the aging in a broader view than strictly biological. Thus, it is imperative to establish connections that are not strictly biological, understanding the multiple factors and concepts, such as old age, which are linked to the aging process. There is not much room for reflection and acknowledgement of old age as a phase in the life cycle of an individual, who, in addition to diseases, has a history, an identity, a social place and health needs. ${ }^{31}$

\section{Perceptions from students and professors - word cloud in figure 3}

Professors' and students' perceptions were mainly related to the structure of nursing course disciplines directed to elderly care. There are multiple bases about the importance of gerontology education in Universities. Teaching this enables change in the concept of old age, benefiting the elderly health care, and especially the interpersonal relationships, which helps to revise prejudice against them.

Students clearly have a perception that the discussion on the aging process at undergraduate level becomes important to the current reality and future professionals who will work with the elderly. Students find discussions interesting, but do not wish to study the subject in a specific discipline, so it could be addressed in other disciplines. They agree that discussing this subject would help them dealing with their families, in addition in helping them to become aware of the political and social issues concerning this population. ${ }^{23}$

Caring relates to sensibility, specialized technical knowledge and social recognition, the reason why it is necessary to create a curricular component in gerontology, insert elderly health theme in all curricular components, as well as the creation of specific groups and practices for teachers/students in Universities to consolidate the learning process. ${ }^{25}$

The investigation significantly contributes with different perceptions, recognizing that the curriculum organization provides in-depth study in gerontology related to elderly health care and allows for the knowledge of the main needs and specificities of this population, as well as to plan interventions and improve assistance. The aim is, therefore, the prevention of diseases and promotion of health, where such knowledge improves training of specialized professionals to assist these clients, which correspond to a large demand of the current population. ${ }^{18}$

Integrality of care contextualizes the aging in a broader view than strictly biological. ${ }^{24}$ Professionals still discuss the curriculum organization, which prevails its attention in the pathological aspects and overspecialization, with little scope for the acknowledgement of old age as a phase of the individuals' life cycle. Individuals who, in addition to diseases, have a history, an identity and social place which inseparable from the health-disease process.

\section{Understanding of old age - word cloud in figure 4}

It is worth noting that aging and old age are distinct terms. Aging is defined in biological terms, while old age is delimited by events of multiple nature, holding a broader meaning. It is possible to understand it as the last phase of a life cycle, marked by multiple events. As the human life cycle extends, old age starts to present subdivisions that meet organizational needs of science and social life. ${ }^{29}$

It is possible to go further through the reflection about the concepts of aging and old age. ${ }^{32}$ "Nothing fluctuates more than the limits of old age in terms of physiological, psychological and social complexity. Is a person as old as his or her arteries, brain, heart, moral or your civil status? Or is it a way in which other people start to face certain characteristics that classifies them as old? " $32: 73$

Aging is generally perceived as something negative. It is also described as a natural process. In fact, it is a fragile and dependent state, in which the elderly need special care. Since the aging process is seen as something that generates dependencies, it characterizes the elderly as old and inefficient. Scholars see the aging process as a physiological, 
biochemical and psycho-emotional set, and, although there are losses that undermine daily activities, at the same time, there may be mechanisms for making good use of their functional capacity. The social understanding is a precept to be contextualized and connected to aging. ${ }^{25}$

Gerontological and geriatric nursing contributes to the formation of future nurses, awakening them to the importance of learning how to take care of the elderly as much as of other human beings. Research grants for future professionals the reconstruction of their conceptions about the object of discussion, and it can unify attitudes of responsibility, autonomy, ethics, analysis and individuation in its formative process. It can also motivate future workers to broaden their views on situations that arise from their work life related to the elderly. The connection established between educational and social knowledge ends up positively influencing the development of appropriate curricula and programs, stimulating professors for a greater exchange on this intensification and, consequently, towards an improved teaching-learning process. ${ }^{21}$

\section{FINAL CONSIDERATIONS}

It was possible to note from articles analyzed in this review the absence of studies that approach competencies to care for the aging, in a more structuralized form, in the undergraduate nursing course. Articles feature curriculum structures, guided by National Curriculum Guidelines for nursing; however, these are mainly formulated in the traditional methodology, focusing on knowledge transmission. The teaching-learning processes found in articles of this review feature little progress, even though some are from before the publication of DCNs, suggesting that over ten years are necessary to implement new curricula and evaluate them for subsequent publication of results.

This review intends to foster the development of new studies that may encourage the education process for competence-oriented care. We aimed at identifying the competencies that permeate nurse's education and thus contribute towards the creation of teaching and learning strategies through generalist training.

The search for solutions to implement what is defined in the guidelines as well as at the Politica Nacional do Idoso (National Elderly Policy), and the adequate teaching and learning strategies in nursing academic education institutions involve the development of competencies needed to care for the elderly. Elderlies should not be considered old adults, since they have their own peculiarities in biological, psychological and social contexts and request specific skills from health professionals.

\section{REFERENCES}

1. Faculdade de Medicina de Marília. Relatório final da Comissão Própria de Avaliação - CPA. Marília (PR): Faculdade de Medicina de Marília; 2006.

2. CameloSHH, Angerami ELS. Professional competence: the building of concepts and strategies developed by health services and implications for nursing. Texto Contexto Enferm [Internet]. 2013 [cited 2015 Jan 13]; 22(2):552-60. Available from: http:/ / www.scielo.br/ pdf/tce/v22n2/v22n2a34.pdf

3. Brasil. Presidência da República. Casa Civil. Lei $n^{\circ}$ 8842, de 4 de janeiro de 1994. Dispõe sobre a Política Nacional do Idoso, cria o Conselho Nacional do Idoso e dá outras providências [Internet]. Diário Oficial da União, Brasília (DF); 5 jan 1994; Seção 1. [cited 2014 Nov 20]. Available from: http:/ / www.planalto.gov. br/ccivil_03/leis/L8842.htm

4. Silva CC, Egry EY. Constituição de competências para intervenção no processo saúde-doença da população: desafio ao educador de enfermagem. Rev Esc Enferm USP [Internet]. 2003 [cited 2014 Dec 13]; 37(2):11-6. Available from: http:// www.scielo.br/pdf/reeusp/ v37n2/02.pdf

5. Roman AR, Friedlander MR. Revisão integrativa de pesquisa aplicada à enfermagem. Cogitare Enferm. 1998; 3(2):109-12.

6. Ganong LH. Integrative reviews of nursing research. Res Nurs Health. 1987;10(1):1-11.

7. Souza MT, Silva MD, Carvalho R. Revisão integrativa: o que é e como fazer. Einstein [Internet]. 2010 [cited 2014 May 30]; 8(1Pt1):102-6. Available from: http:/ / www.astresmetodologias.com/material/O_que_e_ RIL.pdf

8. Ursi ES. Prevenção de lesões de pele no perioperatório: revisão integrativa da literatura. [Internet]. Ribeirão Preto (SP): Universidade de São Paulo, Escola de Enfermagem de Ribeirão Preto; 2005 [cited 2014 Dec 13]. Available from: http://www.teses.usp.br/ teses/disponiveis/22/22132/tde-18072005-095456/ pt-br.php

9. Beyea SC, Nicoll LH. Writing an integrative review. AORN J. 1998; 67(4):877-80.

10. Carvalho PM Jr, Rosa RSL, Sgambatti MS, Adachi EA, Carvalho $\mathrm{Cl}$. Avaliação do programa de residência multiprofissional em saúde da família: uma análise qualitativa através de duas técnicas. Rev Hosp Univ Pedro Ernesto [Internet]. 2012 [cited 2015 Jan 18]; 11(supl1):114-9. Available from: http:/ / revista.hupe. uerj.br/detalhe_artigo.asp?id=319

11. Novaes MRV, Gandolpho MA. A imagem da velhice: a ótica do estudante de Enfermagem. Nursing (São Paulo). 2002; 50(5):19-24. 
12. Santos SMA. Algumas reflexões sobre o ensino da enfermagem geronto-geriátrica na UFSC. Texto Contexto Enferm. 1999; 8(1):174-85.

13. Neri AL, Jorge MD. Atitudes e conhecimentos em relação à velhice em estudantes de graduação em educação e em saúde: subsídios ao planejamento curricular. Estud Psicol [Internet]. 2006 [cited 2014 Nov 20]; 23(2):127-37. Available from: http://www. scielo.br/pdf/estpsi/v23n2/v23n2a03.pdf

14. Silva BT, Santos SSC. Avaliação do ensino da disciplina enfermagem gerontogeriátrica do curso de graduação em enfermagem da FURG. Cogitare Enferm. 2007; 12(1):82-8.

15. Rodrigues RAP, Mendes MMR. Enfermagem gerontogeriatrica: proposta curricular. Rev Paul Enferm. 1993; 12(2):228-35.

16. Kletemberg DF, Padilha MI. Enfermagem gerontológica: a produção do conhecimento na profissão (1970-1996). Rev Gaúcha Enferm. 2013; 34(1):86-93.

17. Oliveira GR, Tavares DMS, Montanholi LL, Simões ALA. Ensino de enfermagem gerontológica na graduação das instituições públicas do estado de Minas Gerais. REME [Internet]. 2007 [cited 2014 Nov 20]; 11(1):26-31. Available from: http://www.reme. org.br/artigo/detalhes/308

18. Tavares DMS, Ribeiro BK, Silva CC, Montanholi LL. Ensino de gerontologia e geriatria: uma necessidade para os acadêmicos da área de saúde da Universidade Federal do Triângulo Mineiro? Cienc Cuid Saúde [Internet]. 2008 [cited 2014 May 15]; 7(4):537-45. Available from: http://www.periodicos.uem. br/ojs/index.php/CiencCuidSaude/article/ viewFile/6671/3921

19. Montanboli LL, Tavares DMS, Oliveira GR, Simões ALA. Ensino sobre idoso e gerontologia: visão dos discentes de enfermagem no Estado de Minas Gerais. Texto Contexto Enferm. 2006; 15(4):663-71.

20. Diogo MJD'E. Graduandos de enfermagem na formação de cuidadores de idosos: relato de experiência. Acta Paul Enferm. 1995; 8(4):76-81.

21. Santos SSC. Oensino da enfermagem gerontogeriátrica e a complexidade. Rev Esc Enferm USP [Internet]. 2006 [cited 2015 Jan 17]; 40(2):228-35. Available from: http://www.scielo.br/pdf/reeusp/v40n2/10.pdf

22. Fraga MNO, Damasceno RN. O ensino de enfermagem geriátrica a partir do domicílio do idoso - relato de experiência. Rev Baiana Enferm. 1998; 4(1):8-11.

23. Freitas MC, Mendes MMR. O ensino sobre o processo de envelhecimento e velhice nos cursos de graduação em enfermagem. Rev Bras Enferm [Internet]. 2003 [cited 2014 Nov 20]; 56(5):502-7. Available from: http://www.scielo.br/pdf/reben/v56n5/a07v56n5. pdf

24. Diogo MJD, Duarte, YAOD. O envelhecimento e o idoso no ensino de graduação em enfermagem no Brasil: do panorama atual à uma proposta de conteúdo programático. Rev Esc Enf USP [Internet]. 1999 [cited 2014 Nov 12]; 33(4):370-6. Available from: http:// www.scielo.br/pdf/reeusp/v33n4/v33n4a08.pdf

25. Medeiros FAL, Araújo DV, Barbosa LNS. Percepção de acadêmicos de enfermagem sobre o cuidar de idosos. Cogitare Enferm [Internet]. 2009 [cited 2014 May 3]; 14(1):85-91. Available from: http://ojs.c3sl.ufpr.br/ ojs/index.php/cogitare/article/view/14120/9491

26. Ladeia EMB, Madureira MDS. Trabalhando o conceito de velhice com o estudante de enfermagem. Rev Med Minas Gerais. 1998; 8(4):152-6.

27. Medeiros FAL, Rodrigues RPL, Nóbrega MML. Visão de acadêmicos de enfermagem em relação ao processo de envelhecimento. Rev Rene. 2012; 13(4):825-33.

28. Ministério da Educação (BR). Conselho Nacional de Educação. Resolução CNE/CES n. 3, de 7 de novembro de 2001. Institui Diretrizes Curriculares Nacionais do Curso de Graduação em Enfermagem [Internet]. Diário Oficial da União, Brasília (DF); 9 nov 2001; Seção 1. [cited 2015 Jan 18]. Available from: http://portal.mec.gov.br/cne/arquivos/pdf/ CES03.pdf

29. Prado SD, Sayd JD. A gerontologia como campo do conhecimento científico: conceito, interesses e projeto político. Cienc Saúde Coletiva [Internet]. 2006 [cited 2014 nov 20]; 11(2):491-501. Available from: http:// www.scielo.br/pdf/csc/v11n2/30436.pdf

30. Araújo DV, Silva CCS, Silva, ATMC. Formação de força de trabalho em saúde: contribuição para a prática educativa em enfermagem. Cogitare Enferm [Internet]. 2008 [cited 2015 Jan 20]; 13(1):10-7. Available from: http://ojs.c3sl.ufpr.br/ojs/index. $\mathrm{php} /$ cogitare/article/view/11944/8428

31. Cecílio LCO. As necessidades de saúde como conceito estruturante na luta pela integralidade e equidade na atenção à saúde. In: Pinheiro R, Mattos RA, organizadores. Os sentidos da integralidade na atenção e no cuidado à saúde. Rio de Janeiro: ABRASCO; 2001. p. 113-26.

32. Veras RP. País jovem com cabelos brancos: a saúde do idoso no Brasil. Rio de Janeiro: Relume Dumará; 1994. 